\title{
Praktik Keagaman Aliran Kejawen Aboge di antara Agama Resmi dan Negara
}

\author{
Moch. Ichiyak Ulumuddin \\ Lembaga Pengkajian Agama dan Masyarakat (LPAM), Surabaya \\ iyakqw@gmail.com
}

\begin{abstract}
Aliran Kepercayaan constitutes a cultural heritage of Indonesia, inherited from generation to generation. Aliran Kepercayaan however have been often measured on the perspective of Indonesian six official religions that eventually bear misjudgment. The divergent of belief system either in terms of religious teachings and practices finally comes as counter argument in responding the existence of Aliran Kepercayaan. This article tries to examine the existence of Aliran Kepercayaan in Mojokerto namely Aboge religiously and socially in relation with the social and political condition of Indonesia. State's constitution indeed guarantees religious freedom for the people to worship in accordance with someone's belief. However, the reality is different at all. Some Aliran Kepercayaan experienced persecution by religious extremist and by the State. Aboge itself often becomes controversial for its Muslim neighborhood. Negative and positive assumption are attached on them in an exchange. Two different interpretations reflect on the Aboge's religious practices and teachings. For this reason, this article attempts to scrutinize the religious practices and teachings in correlation with spiritual tradition on the Javanese people that specialized mysticism in any matters. It also is aimed to explain the state intervention toward the religious life of Aliran Kepercayaan based on the perspective of six official religions.
\end{abstract}

Keywords: Aboge, Religious Practices and Teachings, Kejawen and State Policy. 


\section{Pendahuluan}

Tidak dapat dipungkiri bahwa keberadaan Aliran Kepercayaan dalam masyarakat Indonesia saat ini merupakan suatu kenyataan dari kehidupan spiritual masyarakat sejak dahulu. Subagya berpendapat bahwa Aliran Kepercayaan adalah agama pribumi yang lebih dulu ada sebelum kedatangan agama-agama dunia di Indonesia. ${ }^{1}$ Selain itu, Syafi'i mengutip dari Geertz menyebutkan bahwa terdapat lebih dari 300 suku di Indonesia dan setiap suku mempunyai identitas budaya masing-masing yang menggunakan 250 jenis bahasa yang berbeda dan terdiri dari agamaagama dunia dan agama pribumi. ${ }^{2}$ Hal itu membuktikan bahwa Aliran Kepercayaan merupakan aset penting bagi kehidupan budaya dan agama bangsa Indonesia.

Aliran Kepercayaan dalam kajian akademik merujuk pada kajian agama lokal. Seperti yang diungkapkan oleh David dalam memaparkan tentang agama pribumi, konteks yang sama juga terkandung dalam budaya agama Aliran Kepercayaan yaitu kepercayaan terhadap adanya spirit dalam tiap-tiap benda seperti halnya gunung, pohon, sungai, gua dan lain sebagainya. ${ }^{3}$ Kartapradja juga menegaskan tiga hal tentang Aliran Kepercayaan di Indonesia salah satunya adalah kepercayaan terhadap keberadaan makhluk selain manusia dan kepercayaan akan adanya dewadewa. ${ }^{4}$

Dalam ruang lingkup politik dan sosial, Aliran Kepercayaan mengalami pasang surut dalam perjalanan beragama. Hal tersebut mengacu pada peraturan dan kebijakan pemerintah yang ambigu dalam menyikapi kondisi keberagaman di Indonesia. Negara pada dasarnya menjamin kebebasan setiap warganya untuk memeluk dan beribadah menurut agama dan kepercayaan masing-masing. Namun hanya agama

\footnotetext{
${ }^{1}$ Subagya Rachmat, Agama Asli Indonesia, (Jakarta: Cipta Loka Caraka, 1981), 23.

2 Mufid Syafi'i Achmad, Dinamika Perkembangan Sistem Kepercayaan Lokal Di Indonesia, Kementerian Agama RI, Badan Litbang dan Diklat, Puslitbang Kehidupan Keagamaan, Jakarta 2012, 4.

3 Bird-David, Nurit. ““Animism' Revisited: Personhood, Environment, and Relational Epistemology 1”, in Current Anthropology 40. S1 (1999): S67-S91. 25.

${ }^{4}$ Kartapradja Kamil, Aliran Kebatbinan Dan Kepercayaan Di Indonesia (Jakarta: Yayasan Masagung, 1985), 4.
}

92 | Moch. Ichiyak Ulumuddin - Aliran Kejawen Aboge di antara Agama dan Negara 
yang diakui dan mendapat hak penuh dalam hal keagamaan dan Aliran Kepercayaan seperti dianaktirikan dan tidak diakui dalam kehidupan beragama di Indonesia.

Seperti halnya dalam peraturan Menteri Agama no. 9/1952/pasal 4 yang menyatakan bahwa Aliran kepercayaan merupakan suatu bentuk budaya keterbelakangan yang masih mengacu pada kepercayaan nenek moyang. ${ }^{5}$ Dan juga penafsiran dari undang-undang pasal 29 tahun 1945 yang secara tidak langsung memisahkan antara Aliran kepercayaan dan Agama. ${ }^{6}$

Undang-undang tersebut merupakan wujud ketidakpedulian Negara terhadap Aliran kepercayaan di Indonesia. Pada akhirnya, hal tersebut berimbas kehidupan sosial penganut Aliran kepercayaan seperti halnya masalah terkait dengan administrasi negara yang terkesan mendiskriminasikan penganut Aliran Kepercayaan. Selain itu, lebih lanjut lagi terkait dengan kehidupan sosial penganut Aliran Kepercayaan yang mendapatkan stigma negatif dari masyarakat sekitar yang notabene adalah pemeluk agama mayoritas. ${ }^{7}$ Dari situ, Tedi berpendapat bahwa penafsiran pada pasal 29 tahun 1945 terkait dengan pemisahan antara Agama dan Kepercayaan menjadi penyebab utama dalam isu agama lokal di Indonesia. ${ }^{8}$

Kejawen sebagai salah satu Aliran Kepercayaan tidak luput dari permasalahan tersebut. Sebagai agama asli Jawa, Kejawen adalah cara pandang masyarakat Jawa terkait dengan keagamaan, kepercayaan dan juga tradisi. ${ }^{9}$ Kartapradja menambahkan bahwa Kejawen adalah segala

\footnotetext{
${ }^{5}$ Ramstedt Martin, Hinduism in Modern Indonesia a Minority Religion Between Local, National and Global Interest (Routledge, 2005), 9.

${ }^{6}$ Undang-Undang Dasar Negara Republik Indonesia Tahun 1945. Sekretariat Jenderal MPR RI, 2002. 21.

7 Abbas Langaji, "Dinamika Aliran Keagamaan Sempalan: Tinjauan Perspektif Sosiologi Agama”, dalam Conference Proceeding Annual Internasional Conference on Islamic Studies (AICIS) (2013), 31.

8 Tedi Kholiluddin, Kuasa Negara atas Agama Politik Pengakuan: Diskursus Agama Resmi dan Diskriminasi Hak Sipil (Semarang: Rasail Media Group, 2009), 178.

9 Hakiki, Kiki Muhamad, "Politik Identitas Agama Lokal (Studi Kasus Aliran Kebatinan)", dalam ANALISIS: Jurnal Studi Keislaman 11.1 (2014): 159-174.
} 
sesuatu yang berhubungan dengan tradisi masyarakat Jawa terkait dengan ketuhanan, peribadatan dan kepercayaan di luar agama Islam. ${ }^{10}$ Sebagai bagian dari keragaman agama di Indonesia, keberadaan Aliran Kejawen dalam komunitas agama yang diakui sering kali mendapatkan kecaman dengan alasan bahwa ajaran Kejawen sudah melenceng dari ajaran agama-agama dunia sehingga banyak terjadi kasus diskriminasi di beberapa daerah yang ada di Jawa.

Untuk itu, penelitian ini mengambil salah satu Aliran Kejawen yaitu Aboge yang berada di kabupaten Mojokerto-Jawa Timur sebagai salah satu parameter dalam menganalisis kehidupan beragama penganut agama Jawa dalam konteks sosial dan negara. Aboge merupakan suatu Aliran Kepercayaan yang mengutamakan sisi spiritual dalam praktik keagamaannya. Selain itu, Aboge merupakan identitas spiritual seseorang yang telah mempelajari ilmu hakikat atau ilmu ketuhanan. Aboge mempunyai dua pengertian, pertama adalah merujuk pada sistem kalender Jawa. Aboge terdiri dari tiga kata alif, rebo dan wage yang diartikan sebagai waktu penciptaan alam semesta. Alif merujuk pada istilah tahun pertama dalam putaran delapan tahun dalam kalender Jawa atau windu. Sedangkan Rabo merujuk pada istilah hari dalam satu minggu dan Wage merujuk pada hari pasaran lima. ${ }^{11}$ Dan pengertian kedua merujuk pada status seseorang yang sudah mencapai tingkat tertentu dalam hal spiritualitas.

Terkait dengan kegiatan keagamaan, orang Aboge mempunyai cara tersendiri dalam menjalankan praktik keagamaannya. Ritual bagi orang Aboge merupakan hal personal yang mana ritual tersebut merupakan suatu bentuk cara untuk lebih mendekatkan diri dengan yang maha kuasa. Setiap Aboge mempunyai cara tersendiri dalam melaksanakan kegiatan keagamaannya. Hal tersebut tergantung pada tiap individu artinya tidak terikat pada aturan khusus dalam suatu komunitas keagamaan tertentu. Ritual Aboge tergolong sebagai ritual yang luar biasa dalam artian tidak biasa dilakukan oleh kebanyakan orang seperti halnya ritual ngembong yang mana berjalan kaki dari satu tempat ke tempat lain

${ }^{10}$ Kamil Kartapradja, Aliran Kebatbinan Dan Kepercayaan Di Indonesia (Jakarta: Yayasan Masagung; 1985), 5.

${ }^{11}$ Condro Mulya, Wawancara, 19 Mei 2013.

$94 \mid$ Moch. Ichiyak Ulumuddin - Aliran Kejawen Aboge di antara Agama dan Negara 
tanpa melihat jarak dan lokasi dan mbegendeng yang mana berperilaku seperti layaknya orang gila. Ritual-ritual tersebut merupakan jalan untuk mencapai penyatuan diri dengan sang maha kuasa atau Tuhan.

Dalam kehidupan sosial, ritual dan ajaran Aboge sering kali dipandang negatif oleh kebanyakan orang sekitar mereka. Sebagian masyarakat di Mojokerto menganggap bahwa praktik tersebut adalah praktik sesat yang menyimpang dari ajaran agama. Namun sebagian kecil masyarakat menganggap bahwa praktik dan ajaran tersebut merupakan bentuk tradisi spiritual keagamaan Jawa. Dari sini, penelitian ini mencoba untuk menjabarkan secara singkat terkait dengan praktik keagamaan orang Aboge beserta dengan ajarannya. Selain itu, penelitian ini mencoba untuk mempermasalahkan kerumitan kehidupan beragama di Indonesia. Seperti yang sudah dijelaskan di beberapa literatur bahwa rumitnya kehidupan beragama di Indonesia dikarenakan oleh aturan Negara yang ambigu dengan nilai-nilai kebebasan beragama.

\section{Ajaran Aboge}

Aboge merupakan Aliran Kejawen yang ada di Mojokerto-Jawa Timur. Aliran ini tidak mempunyai struktur kelembagaan seperti halnya Aliran Kejawen pada umumnya. Aliran Aboge merupakan kelompok spiritual yang berada di berbagai tempat di Mojokerto. Mereka lebih dikenal dengan orang kebatinan. Pada saat ini kebanyakan penganut Aboge tinggal di Mojokerto namun mereka tidak di satu lokasi tertentu melainkan menyebar ke beberapa tempat di Mojokerto, Sidoarjo dan Surabaya. Ada juga beberapa dari mereka yang memilih hidup di suatu tempat terpencil misalnya di gua dan di hutan area sekitar gunung welirang dan penanggungan yang ada di Mojokerto. ${ }^{12}$

Aliran Aboge pada dasarnya mengacu pada pencapaian spiritual dalam kehidupan manusia. Hal ini mengacu pada pemahaman seseorang terkait spiritualisme yang merujuk pada pertanyaan ontologi yaitu tentang keberadaan manusia di dunia. Aboge adalah sebuah label bagi mereka yang sudah mencapai tingkat tertentu dalam hal spiritualisme.

${ }^{12}$ Mojo Kusumo, Wawancara, 6 Maret 2015. 
Pemahaman spiritualitas ini mengacu pada ilmu kebatinan atau mistisisme Jawa terkait dengan pemahaman eksistensi manusia dan ketuhanan. Dengan demikian, Aboge merupakan suatu identitas spiritual tradisi keagamaan masyarakat Jawa.

Terdapat dua definisi terkait dengan istilah Aboge. Pertama, kata Aboge merujuk pada sistem kalender Jawa yang berarti waktu penciptaan alam semesta. Aboge dalam bahasa Jawa terdiri dari tiga kata yaitu "Alip, Rebo dan Wage". Alip berasal dari "Alif" sebuah huruf Arab mengacu pada "Tahun Siji" (tahun pertama dalam siklus delapan tahun atau windu), Rebo adalah istilah Jawa mengadaptasi dari bahasa Arab "Robi'a" yakni nama hari dalam siklus tujuh hari, dan Wage merupakan salah satu istilah dalam kalender Jawa terkait dengan "Hari Pasaran" yang terdiri dari Pon, Wage, Kliwon, Legi, dan Pabing. Dalam sistem kalender Jawa dimaknai sebagai Tahun siklus delapan tahun yang jatuh pada tahun Alip yang jatuh pada hari Rebo dan hari pasaran Wage. Kedua, istilah Aboge merujuk pada tingkat spiritual manusia terkait dengan ilmu kebatinan. Penjelasan lain yaitu sebuah istilah dalam ajaran kebatinan Jawa yang ditujukan kepada orang-orang yang mempelajari Ilmu Hakikat atau Ilmu Ketuhanan. ${ }^{13}$

Sehubungan dengan penjelasan di atas, setiap orang Aboge mempunyai cara tersendiri dalam kaitannya dengan praktik dan ajaran keagamaan. Oleh karena itu, dapat diartikan bahwa orang Aboge adalah sekelompok orang dari beberapa tempat yang berbeda yang mempelajari tentang mistisisme dengan cara berbeda dan prosedur pada tiap individunya.

\section{Praktik Ritual Aboge}

Ada banyak bentuk ritual keagamaan dalam praktik keagamaan dan ajaran Aboge. Ritual orang Aboge merupakan suatu intersubjektif relation yang mengacu pada konsep "Manunggaling" atau penyatuan. Orang Aboge memahami bahwa ada makhluk lain selain manusia yang hidup dan tinggal di alam semesta ini. Yang termasuk dalam kategori selain

${ }^{13}$ Condro Mulyo, Wawancara, 21 Februari 2015.

96 Moch. Ichiyak Ulumuddin - Aliran Kejawen Aboge di antara Agama dan Negara 
manusia di sini adalah pohon, gunung, sungai, batu, hewan dan lain sebagainya. Aboge memahami mereka (non-manusia) adalah person/orang yang merupakan bagian dari kehidupan manusia. Dalam konteks ini, Aboge memahami bahwa untuk dapat bersatu manusia harus bias memahami keberadaan person lain (makhluk non-manusia) sebagai wujud dari eksistensi yang maha kuasa. Selain itu, orang Aboge memahami non-manusia mempunyai jiwa seperti manusia. Oleh karena itu, sikap yang diutamakan dalam perilaku orang Aboge adalah menghargai mereka layaknya manusia lain.

Dalam kaitannya dengan ritual Aboge, ritual tersebut dimaksudkan untuk menyinkronkan setiap elemen kehidupan termasuk manusia dan makhluk non-manusia agar bias bersatu dengan zat yang maha agung atau dalam artian Manunggal (bersatu dengan Tuhan). Untuk alasan tersebut, ritual adalah sebuah penyegaran kembali hubungan antar subjek antara manusia dan non-manusia untuk mencapai tahap Manunggaling.

Praktik-praktik keagamaan dari Aboge disebut juga Laku. Laku berasal dari bahasa Jawa yang artinya suatu kegiatan spiritual untuk meningkatkan spiritualitas seseorang dalam hal spiritualisme. Tidak ada aturan khusus melakukan Laku. Dalam prosedurnya, ada dua cara Laku yaitu individu dan kelompok. Cara individu yaitu kegiatan yang dilakukan secara personal dalam bentuk dan pola yang berbeda tiap individunya. Dan cara komunal yaitu dilakukan oleh beberapa orang berdasarkan pedoman yang dari Guru.

Laku dalam pemahaman orang Aboge adalah urusan personal. $\mathrm{Hal}$ ini karena tiap individu mempunyai cara dan tujuan tersendiri dalam melaksanakan Laku. Selain itu, tidak ada ketetapan waktu dan lokasi dalam menjalankan Laku. Sementara itu berbeda dengan Laku dalam kaitannya dengan Aboge dalam suatu kelompok. Sering kali Laku yang akan dikerjakan tergantung pada sesepuh atau guru spiritual mereka. Jadi, meskipun terdapat prosedur yang berbeda terkait dengan Laku (secara individu dan kelompok), praktik keagamaan ini memiliki tujuan yang sama yaitu untuk dapat bersatu dengan Tuhan atau "Manunggaling Kawulo Gusti". Di bawah ini, beberapa praktik Laku dalam pemahaman orang Aboge. 


\section{Ritual Mbegendeng}

Ritual Mbegendang, berasal dari istilah Jawa Gendeng yang berarti Crasy, merupakan suatu ritual individu yang dilakukan untuk meninggalkan kehidupan biasa di belakang. Ini ritual berfungsi sebagai cara untuk memotong hubungan dengan manusia lainnya sehingga hanya kiri adalah hubungan antara praktisi dan Ilahi. Mbegendeng di arti harfiahnya adalah "Laku Gila" (praktik gila). Ini mewajibkan seseorang untuk berpura-pura dan bertindak seperti orang gila, mengenakan pakaian beberapa aneh atau pergi ke beberapa tempat dan itu sebagian besar menyukai orang gila. Dalam hal ini, orang akan menganggap praktisi sebagai orang gila. Ritual ini berarti menyebabkan asumsi negatif dari orang-orang terhadap dirinya sehingga hubungan manusia-manusia akan hilang dan lebih terakhir adalah hubungan mereka dengan Tuhan. ${ }^{14}$

\section{Ritual Ngembong}

Ritual ngembong adalah semacam perjalanan ke tempat tertentu tidak peduli berapa lama waktu dan jauh tempat yang dituju sesuai dengan petunjuk yang didapatkan. Ngembong adalah istilah lain untuk "Embong" yang berarti "Jalan". Umumnya, itu merupakan praktik hidup di jalan tanpa bekal dan ketentuan selama melakukan perjalanan tersebut. Ritual ini juga dikenal sebagai "Lungo Kaji". "Lungo" berarti "Pergi" dan “Kajı” berarti “Hajı”. Dalam arti lengkap, melakukan berziarah. ${ }^{15}$ Tujuan dari Laku ini adalah untuk mencari Ilmu Sejati (pengetahuan benar) dan mendapatkan jawaban-jawaban dari pertanyaan seputar ketuhanan dan eksistensi manusia. Tidak jarang juga untuk mencari kesaktian atau kesaktian (dalam bahasa Jawa) seperti mampu menyembuhkan orang sakit tanpa dan kemampuan melihat roh-roh orang mati, jin dan lain sebagainya. ${ }^{16}$ Ritual ini termasuk dalam kategori ritual individu tapi juga bias dilakukan secara kelompok. Perbedaannya adalah tentang waktu dan tempat. Dalam cara individu, tidak ada ketentuan pasti waktu dan tempat sedangkan dalam kelompok, waktu dan tempat sering ditentukan oleh guru spiritual dalam suatu Aliran kepercayaan tertentu misalnya

\footnotetext{
${ }^{14}$ Mas Bagas, Wawancara, 17 Januari 2015.

${ }^{15}$ Condro Mulyo, Wawancara, 19 Februari 2015.

16 Pak Budi, Wawancara, 25 Februari 2015.
}

98 Moch. Ichiyak Ulumuddin - Aliran Kejawen Aboge di antara Agama dan Negara 
perjalanan ke puncak gunung Arjuna yang dilakukan setiap tahun oleh sebagian penganut Aliran Kejawen di Jawa.

3. Ritual Poso

Ritual "Poso" atau puasa merujuk pada pengertian menahan hawa nafsu untuk makan, minum, berbicara, seks dan sebagainya. Orang Aboge memahami bahwa nafsu manusia tidak hanya berkisar tentang nafsu makan dan minum akan tetapi juga nafsu lainnya seperti berbicara, mendengar dan seksualitas. Poso juga erat kaitannya dengan "Roso/Rasa." Oleh karena itu, Poso didefinisikan sebagai Ngeposno Roso atau mengekang hawa nafsu. Ritual ini tergolong dalam ritual individu yang bertujuan untuk menahan nafsu manusia sehingga bias merasakan rasa sejati atau Sejatine Roso. Hal itu berarti rasa tidak hanya mencakup tentang rasa dalam pengertian umum duniawi akan tetapi dibalik rasa itu ada tingkat rasa yang tertinggi yaitu Roso Sejati atau Sejatine Roso. ${ }^{17}$ Dalam ajaran agama Jawa, ada banyak bentuk Poso seperti: Poso Pati Geni yang tidak boleh terkena sinar matahari, Poso Mutih yang hanya makan nasi putih dan air putih, Poso Weton atau puasa berdasarkan waktu kelahiran, Poso Ngalong atau puasa dengan cara tidak tidur selama beberapa hari siang dan malam dan lain sebagainya. ${ }^{18}$

\section{Ritual Sembahyang}

Ritual sembahyang atau disebut juga Sesembahan Sanghyang yaitu penyembahan terhadap Tuhan yang maha esa. Ritual Ini adalah ritual umum yang rutin dilakukan oleh setiap orang Kejawen. Sembahyang tidak dibatasi oleh waktu, tempat atau ruang. Sembahyang mempunyai bermacam bentuk dan pola tergantung pada ajaran yang diterima oleh pelaku ritual. Ritual ini juga disebut sebagai Neng Ning, yang berarti

\footnotetext{
${ }^{17}$ Condro Mulyo, Wawancara, 19 Februari 2015.

18 Mas Jalal, Wawancara, 1 Maret 2015. Beliau memaparkan macam-macam puasa yaitu (Poso Pati Geni berarti puasa yang tidak boleh terkena sinar matahari dan harus berada di tempat yang gelar Poso Moteh berarti puasa yang hanya makan nasi putih dan minum air putih pada waktu buka dan sahur. Poso Ngebleng yaitu puasa sambil begadang alias tidak tidur selama beberapa hari selama waktu yang ditentukan. Dan Poso Amalan yaitu puasa sambil merapalkan doa/amalan yang diberikan oleh Guru spiritual. Dan Poso Weton atau puasa untuk merayakan waktu kelahiran.
} 
Ngeningno Cipto atau diam mengheningkan cipta. Dalam istilah lain, itu disebut Topo Sesaat (meditasi sesaat). Ritual ini bertujuan untuk meninggalkan semua kepentingan dunia dan mulai berinteraksi dengan Ilahi di alam semesta. ${ }^{19}$

\section{Ritual Bersama}

Ritual bersama adalah ritual yang dilakukan oleh beberapa orang untuk memperingati suatu peristiwa tertentu. Ritual bersama ini dilakukan di Pendopo Agung Troloyo-Mojokerto. Ritual ini biasanya diadakan pada bulan Suro, bulan pertama dalam kalender Jawa dari dua belas bulan dalam siklus satu tahunan. Ritual ini dimaksudkan untuk menyambut tahun baru Jawa (Suroan). Hari pertama di bulan Suro yang merupakan hari suci dan bulan menurut perspektif orang Jawa. Ritual ini berupa doa bersama dengan penganut Aliran Kejawen lain. Dalam acara tersebut, ada sesajen seperti bunga dengan tujuh warna, tujuh sumur air, beras kerucut, dupa dan lain-lain. Nama untuk sesajen tersebut adalah Skul Gondo Arum (makanan yang berbau harum). Sesajen ini sebagai bentuk penghormatan kepada leluhur agar dilindungi dalam segala bentuk aktivitas yang akan dilakukan.

Ritual-ritual tersebut merupakan hal yang menarik dalam kajian religious studies karena erat kaitannya dengan keyakinan seseorang namun beberapa ritual dinilai kontradiktif dalam kehidupan sosial, Negara dan institusi agama di bawahnya. Kaitannya dengan kehidupan sosial, sebagian orang Mojokerto yang notabene adalah pemeluk agama Islam menilai bahwa ritual-ritual tersebut merupakan penodaan dan penyelewengan agama karena tidak relevan dengan agama yang sudah ditetapkan oleh pemerintah.

Ada dua opini masyarakat terkait dengan ritual orang Aboge. Pertama sebagian besar masyarakat di Mojokerto melihatnya sebagai suatu hal yang menyimpang dari ajaran agama Islam namun sebagian kecil menganggap bahwa ritual tersebut merupakan ritual asli ajaran agama Jawa.

${ }^{19}$ Mas Jalal, Wawancara, 1 Maret 2015.

100 Moch. Ichiyak Ulumuddin - Aliran Kejawen Aboge di antara Agama dan Negara 
Pernyataan kasar terkait dengan hal itu adalah label sesat, gila, aneh dan lain sebagainya yang disematkan oleh sebagian besar masyarakat terhadap penganut Aliran Aboge. Bahkan karena label tersebut, salah satu penganut Aliran Aboge pada tahun 2010 hampir diusir oleh sebagian orang yang ada di sana termasuk juga pejabat desa. Jika menganalisis hal tersebut, tidak bias dipungkiri bahwa Aliran kepercayaan memang bukan termasuk dalam kategori agama di Indonesia melainkan sebagai bentuk kebudayaan. Dengan kata lain, stigma negatif terhadap penganut Aliran tersebut juga dikarenakan oleh campur tangan Negara dalam mengatasi keragaman agama di Indonesia.

Dengan demikian, jika menghubungkan dengan peraturan Negara dan lembaga yang khusus menangani Aliran kepercayaan seperti Bakorpakem, maka ritual tersebut akan menjadi masalah serius. Hal ini karena ritual tersebut akan dianggap sebagai penghujatan dan penyalahgunaan terhadap salah satu agama yang berlaku di Indonesia. Seperti yang disebutkan dalam Undang-Undang PNPS tahun 1965 tentang pencegahan penodaan agama dan penyalahgunaan dalam pasal 1 nomor 2 yang singkatnya mengatakan bahwa seseorang dilarang di muka umum melakukan penafsiran terhadap agama dan melakukan kegiatankegiatan yang mirip dengan agama yang berlaku.

Dengan adanya undang-undang tersebut, negara melalui Bakorpakem bertindak untuk menghentikan kegiatan tersebut. Namun, perlu juga adanya syarat-syarat lain seperti halnya rekomendasi dari lembaga keagamaan tertentu seperti Majelis Ulama Indonesia (MUI) untuk menilai kegiatan tersebut. Oleh karena itu, ritual Aboge kaitannya dengan sosial erat hubungannya dengan negara dan Bakorpakem sebagai eksekutornya. Dengan demikian, praktik-praktik ritual di luar enam agama akan dianggap sebagai praktik ilegal yang harus dihentikan dan dihukum sesuai dengan ketentuan yang berlaku.

\section{Kehidupan Orang Aboge}

Kehidupan sosial dan ekonomi orang Aboge tidak berbeda jauh dengan orang lain pada umumnya. Ada beberapa dari mereka hidup rukun ditengah-tengah masyarakat namun ada juga yang mengasingkan 
diri jauh dari masyarakat. Mayoritas masyarakat di sekitar orang Aboge adalah Muslim.

Sehubungan dengan praktik agama dan ajaran Aboge dalam konteks kehidupan sosial, ada dua asumsi yang melekat pada mereka. Pertama, masyarakat cenderung melihat kegiatan keagamaan Aboge dengan sudut pandang negatif dan kedua sudut pandang positif. Pada satu sisi, masyarakat mengakui Aliran Aboge sebagai suatu kelompok sesat karena kegiatan mereka yang mengarah pada animisme dan dinamisme dan juga aneh karena ritual keagamaan yang dilakukan dinilai keluar dari agama dan kebiasaan manusia normal. Selain itu, status tidak beragama juga sempat dilabelkan pada penganut Aliran Aboge karena ketidakjelasan dalam ajaran dan ritual orang Aboge. Namun, di sisi lain sebagian masyarakat mengakui keberadaan mereka sebagai suatu tindakan tradisi spiritual agama Jawa. Sehingga terkadang mereka dijuluki sebagai "Orang Ngerti, Pinter dan Wali". Dua perspektif yang berbeda dialamat kepada orang Aboge oleh sebagian masyarakat yang tinggal di sekitar orang Aboge.

Di Indonesia orang sering menganggap keberadaan agama lokal sebagai kemunduran, bodoh, tidak bertuhan, dan menyimpang. Sering kali label-label tersebut berkaitan dengan pandangan orang-orang terkait dengan apa yang mereka percayai, praktikkan dan pelajari. Selain itu, legitimasi negara yang tidak mengakui agama lain selain Islam, Konghucu, Buddha, Hindu, Katolik dan Kristen menjadi salah satu faktor terbentuknya stigma negatif yang ada di masyarakat. ${ }^{20}$

Kondisi tersebut sama dengan apa yang stigma negatif terhadap Aliran Aboge, sebagian besar Muslim di Mojokerto melihat bahwa orang Aboge sebagai kelompok orang sesat, murtad dan tidak beragama. Selain itu, label orang gila juga sempat diberikan kepada salah satu penganut Aliran Aboge karena perbuatan salah seorang Aboge sama dengan orang gila. Kategori animisme juga sempat melekat pada kelompok ini ketika ada orang Aboge yang dinilai menyembah matahari, bulan dan bumi. Beberapa pandangan ini diungkapkan oleh guru ngaji dan juga imam salat Jumat di daerah Pesanggrahan-Mojokerto dan bahkan menyarankan

${ }^{20}$ Cak Ranto, Wawancara, 15 Januari 2015.

102 | Moch. Ichiyak Ulumuddin - Aliran Kejawen Aboge di antara Agama dan Negara 
kepada pemerintah tindakan pencegahan sehingga membawa penganut Aboge kembali ke ajaran Islam. Demikian asumsi negatif yang sempat melekat pada orang Aboge karena tindakan keagamaan yang dinilai melecehkan agama Islam. Berbeda dengan sebagian kecil masyarakat yang pernah mendalami ilmu Kejawen, kegiatan agama tersebut dianggap sebagai cerminan ajaran asli Jawa.

Asumsi lain yang bermunculan dalam pandangan sebagian kecil masyarakat muslim di Mojokerto adalah sebagai orang yang memiliki pemahaman lebih jauh tentang ketuhanan. Kadang mereka dianggap sebagai Wong Ngerti (orang bijak), Wong Pinter (orang penuh pengetahuan), dan kadang juga menyamakan dengan $W$ ali atau dalam istilah Islam berarti kekasih Allah. Hal ini dikarenakan tindakan dan kemampuan orang Aboge melebihi kemampuan orang biasa pada umumnya seperti halnya dapat mengobati orang yang sakit, melihat makhluk halus dan juga keistimewaan-keistimewaan lainnya. Beberapa dari masyarakat percaya bahwa ketika manusia telah mencapai tingkat tertentu dalam kehidupan spiritualitasnya maka orang tersebut sudah hampir mencapai kesempurnaan sejati. Oleh karena itu, sebagian kecil orang menganggap mereka sebagai orang-orang pilihan, orang-orang suci, dan orang-orang yang memahami jati diri mereka sendiri.

Dengan demikian, dapat disimpulkan bahwa ada dua sisi dalam hal melihat Aliran Aboge di masyarakat Muslim Jawa. Beberapa dari mereka tidak setuju dengan keberadaan mereka dan juga menurunkan Aliran Aboge karena tidak sejalan dengan Islam apalagi itu bukan bagian dari agama resmi di Indonesia. Tapi, di sisi lain beberapa dari mereka setuju dengan atau dapat dikatakan tidak mempermasalahkan keberadaan Aliran Aboge dalam masyarakat Muslim Jawa untuk mereka menggambarkan arti sebenarnya dari cara hidup orang Jawa dan tradisi.

\section{Ajaran Aboge di antara Ajaran Kejawen Lainnya}

Ajaran agama Aboge tidak memiliki banyak perbedaan dengan Aliran Kejawen pada umumnya. Mereka memiliki pemahaman yang hampir sama dengan Aliran Kejawen lainnya terkait dengan ketuhanan, alam dan manusia. Perbedaannya mungkin lebih terkait dengan nama- 
nama dan istilah yang digunakan dalam menyebutkan keyakinan mereka. Namun, poin utama dalam ajaran mereka adalah "Manunggaling Kawulo Gusti". Dalam hal ini, berikut disebutkan beberapa hal terkait dengan ajaran Aliran Aboge.

\section{Pemahaman tentang Ketuhanan}

Dalam ajaran Aboge, Tuhan dianggap sebagai hal kosmologis dan tak berwujud. mutlak dan berada dalam segala sesuatu di alam semesta. Tuhan terletak di tempat tertentu di mana hanya orang-orang dengan tingkat spiritualitas tertentu yang dapat memahaminya. Tuhan tidak memiliki nama. Aboge percaya bahwa Tuhan itu satu namun bermanifestasi dalam segala sesuatu di alam semesta ini.

Paham ketuhanan tersebut mirip dengan Aliran Pangestu (Paguyuban Ngesti Tunggal). Tuhan tidak hanya hal tentang transenden tetapi juga hadir. Tuhan tidak pasif atau statis tetapi memiliki "Karsa" (kehendak) sehingga kehadirannya dapat dirasakan oleh manusia. Tuhan bukanlah laki-laki atau perempuan, tidak ada awal dan juga berakhir, tidak memiliki anak atau menjadi anak. Konsep ketuhanan dalam Aliran ini adalah Monoteisme-Tripurusa yaitu satu tuhan dengan tiga sifat. Meskipun ada perbedaan dalam konsep ketuhanan secara konkret namun persamaannya adalah tuhan dipandang sebagai subjek yang universal yang mampu terwujud dalam segala sesuatu di dunia ini.

\section{Pemahaman Kemanusiaan}

Manusia adalah manifestasi Tuhan. Manusia terdiri dari tubuh fisik dan tubuh bagian dalam. ${ }^{21}$ Setiap manusia mempunyai dengan "Dulur". Dulur adalah makhluk mistis yang mempunyai perwujudan yang sama dengan manusia itu sendiri. Dengan kata lain, Dulur merupakan saudara kembar manusia yang ada di dimensi lain. Selain itu, manusia adalah Rosul atau utusan Tuhan yang memiliki empat kewajiban; kewajiban terhadap diri mereka, kewajiban kepada Allah, alam dan manusia lainnya. ${ }^{22}$

${ }^{21}$ Condro Mulyo, Wawancara, 19 Februari 2015.

22 Mas Jalal, Wawancara, 1 Maret 2015.

104 Moch. Ichiyak Ulumuddin - Aliran Kejawen Aboge di antara Agama dan Negara 


\section{Pemahaman tentang Alam}

Alam merupakan makhluk Tuhan sama seperti manusia. Alam meliputi matahari, gunung, pohon, bumi, hewan dan sebagainya adalah makhluk hidup. Mereka hidup berdampingan dengan manusia, berbagi dan menyembah kepada Tuhan dalam cara tertentu. Orang Aboge percaya bahwa matahari yang bergerak mengikuti arahnya adalah contoh dari penyembahan terhadap Tuhan yang dilakukan oleh matahari.

\section{Pemahaman Tentang Kehidupan Setelah Kematian}

Orang Aboge tidak mengenal kehidupan setelah kematian namun mereka mengenal istilah reinkarnasi. Selain itu, tidak ada istilah surga dan neraka dalam ajaran orang Aboge namun orang Aboge memandang surga dan neraka ada dalam kehidupan dunia. Orang Aboge percaya bahwa neraka dan surga adalah emosi manusia ketika mereka berurusan dengan momen emosional tertentu seperti kesedihan dan kebahagiaan. Reinkarnasi dalam pandangan orang Aboge adalah ketika seseorang meninggal dia akan dibangkitkan sebagai manusia lagi dengan bentuk dan tujuan yang berbeda.

\section{Pemahaman tentang Karma}

Hukum karma juga bekerja ajaran Aboge. Mereka percaya pada sebab dan akibat dari tindakan manusia, apakah itu baik atau buruk. Semuanya akan berdampak di masa depan. Selain itu, Karma dalam pandangan Aboge ini dapat diturunkan dari generasi ke generasi.

Demikian adalah ajaran dan praktik keagamaan orang Aboge. Jika melihat sekilas tentang hal tersebut, pemahaman-pemahaman tersebut merupakan salah satu bentuk ajaran tradisi Kejawen yang mana pemahaman tentang ketuhanan, alam dan manusia mempunyai keterkaitan satu sama lain sehingga sikap yang muncul adalah tindakan nyata dibarengi dengan kepercayaan mereka yang melandasi sikap hidup agama Jawa. 


\section{Kebijakan Negara Indonesia dalam Mengawasi Agama Lokal}

Agama mempunyai peran penting dalam kehidupan berbangsa dan bernegara di Indonesia. Agama telah menjadi hal yang sangat sensitif dalam perkembangan masyarakat di Indonesia. Untuk kebijakan menjadi salah satu cara untuk menjaga kedamaian antar warga yang memiliki latar belakang agama yang berbeda. Dunn mengartikan bahwa kebijakan publik merupakan sebuah cara pemerintah dalam mengatur kehidupan warganya. ${ }^{23}$ Untuk itu, kebijakan sebagai suatu kewajiban pemerintah dalam menjalankan tugasnya untuk menjaga stabilitas dan juga mengayomi warga negaranya.

Kebijakan agama di Indonesia menjadi salah satu kebijakan publik yang perlu diteliti lebih lanjut. Pasalnya kebijakan agama di Indonesia terkesan tidak merata dan hanya menguntungkan salah satu pihak yaitu enam agama yang diakui oleh Negara. ${ }^{24}$ Sedangkan kebijakan bagi Aliran Kepercayaan yang notabene adalah agama asli menjadi terpinggirkan.

Salah satu bentuk kebijakan yang dinilai kontroversi adalah pertama tentang definisi agama di Indonesia. Pada tahun 1952-1955, Negara melalui kebijakannya memutuskan definisi agama di Indonesia yang mengacu pada agama besar dunia seperti halnya bertuhan, mempunyai nabi, ada kitab dan pengikut. ${ }^{25}$ Dari sini dapat dilihat bahwa Aliran kepercayaan tidak termasuk dalam kategori tersebut, sebagai suatu bentuk agama melainkan budaya masyarakat. Oleh karena itu, agama lokal atau Aliran kepercayaan berstatus belum agama yang berujung pada stigma negatif yang berkembang di masyarakat seperti halnya sesat, terbelakang dan kuno. Istilah belum beragama ini seolah-olah menjadi acuan dalam menetapkan baik dan buruk seseorang. Picard dalam hal ini menilai bahwa definisi Agama dalam konteks Indonesia tidak sesuai dengan kondisi keagamaan masyarakat Indonesia yang tidak hanya terdiri

\footnotetext{
23 Syafiie, Inu Kencana dkk. Ilmu Administrasi Publik, Jakarta: PT Rineka Cipta, 1999. 107

24 Picard and Medinier, The Politics Of Religion In Indonesia (New York: Routledge, 2011), 5 .

25 Ibid, 3.
}

106 | Moch. Ichiyak Ulumuddin - Aliran Kejawen Aboge di antara Agama dan Negara 
dari pemeluk agama-agama dunia tetapi juga agama lokal. Konteks agama di Indonesia mencerminkan Islam dan Kristen sebagai agama mayoritas di Indonesia. ${ }^{26}$

Selanjutnya, Negara hanya menyebutkan Islam, Buddha, Hindu, Kristen, Katolik dan Khong $\mathrm{Hu} \mathrm{Cu}$ sebagai agama-agama yang diakui oleh negara. Selain itu, kemunculan undang-undang tahun 1965 PNPS No. 1 dan 1969 Nomor 5 tentang pemisahan antara agama dan Aliran kepercayaan menjadi sangat jelas. ${ }^{27}$ Ditambah lagi dengan, peraturan pemerintah dalam Keputusan MPR (Majelis Permusyawaratan Rakyat) nomor IV / MPR / 1978 yang menegaskan bahwa Aliran Kepercayaan atau kelompok agama lokal bukan merupakan agama. ${ }^{28}$ Dengan begitu, status belum beragama dirasakan oleh sebagian besar masyarakat Indonesia terhadap kelompok-kelompok Aliran kepercayaan yang akhirnya menambah kisruh kehidupan agama di Indonesia.

Kedua adalah posisi Aliran Kepercayaan di Indonesia yang pada saat ini dialihkan di bawah naungan Menteri Kebudayaan dan Pariwisata yang sebelumnya diserahkan kepada Kementerian Agama. Pemindahan tugas ini pada dasarnya mengarahkan pada asumsi bahwa Aliran Kepercayaan memang bukan suatu bentuk keagamaan melainkan sebagai ekspresi budaya masyarakat Indonesia.

Ketiga adalah tentang keberadaan Bakorpakem yang memiliki kewenangan hukum untuk menentukan mana yang termasuk dalam kategori agama dan mana yang bukan agama. Bakorpakem berfungsi untuk mengawasi agama baru seperti yang disebutkan oleh undangundang No.16/2004 khususnya pasal 33 ayat 3 huruf (d) dan (e) terkait

\footnotetext{
${ }^{26} \mathrm{Ibid}, 13$.

${ }^{27}$ Kholiluddin, Kuasa Agama Atas Negara, Pengakuan, 230.

${ }^{28}$ Sairin, Weinata, and Joseph Marcus Pattiasina. Pelaksanaan Undang-Undang Perkawinan

Dalam Perspektif Kristen: Himpunan Telaab Tentang Perkawinan Di Lingkungan Persekutuan Gereja-Gereja Di Indonesia. (Jakarta: BPK Gunung Mulia, 1994), 321. Di sini dijelaskan bahwa kepercayaan kepada Tuhan yang maha esa bukanlah agama akan tetapi bagian dari kebudayaan dan penganut agama besar yang mengikuti aliran kepercayaan tidak kehilangan status agama mereka. Oleh karena itu, tidak ada prosedur pernikahan dan peraturan terkait dengan aliran kepercayaan.
} 
dengan peran serta kejaksaan untuk mengawasi kepercayaan/agama, dan juga untuk pencegahan dan penodaan agama. ${ }^{29}$

Latar belakang dan tujuan dari pembentukan tim ini mengacu pada Keputusan Jaksa Agung Nomor Kep-108/JA/5/1984 tentang pembentukan Tim Koordinasi Aliran Kepercayaan Masyarakat. Setidaknya disebutkan bahwa Tim dibentuk sesuai dengan keputusan yang ditujukan untuk yaitu untuk pembinaan dan pengawasan terhadap Aliran Kepercayaan dengan beberapa tujuan sebagai berikut: (1) Sehingga kepercayaan terhadap Tuhan Yang Maha Esa tidak menjadi formulasi agama baru; (2) Memungkinkan pengambilan langkah-langkah atau tindakan tegas terhadap Aliran Kepercayaan dalam hal membatasi dari tindakan merugikan masyarakat dan negara; dan (3) Pelaksanaan Aliran Kepercayaan di bawah yurisdiksi yang tepat sesuai dengan prinsip dasar kemanusiaan yang adil dan beradab. Namun pada praktiknya, tugas Pakem menjadi begitu banyak terlihat dalam mengawasi Aliran Kepercayaan dan sekte dalam agama-agama resmi yang diasumsikan potensi penyimpangan terhadap agama yang diakui oleh negara. ${ }^{30}$

Dari beberapa hal tersebut sangat jelas intervensi Negara terhadap kehidupan beragama di Indonesia khususnya terkait dengan Aliran kepercayaan. Melalui beberapa kebijakan yang berlaku Negara hanya memberikan sedikit ruang terhadap Aliran kepercayaan untuk mengaplikasikan ajaran dan kepercayaannya. Selain itu, melalui kebijakan itu Negara memetakan agama dan kepercayaan sebagai suatu hal yang berbeda.

\section{Penutup}

Dari sini dapat ditarik kesimpulan bahwa orang Aboge di Jawa timur merupakan salah satu bentuk Aliran Kejawen yang memiliki karakteristik tertentu dalam melaksanakan praktik dan ajaran agama mereka. Aboge adalah identitas spiritual bagi orang-orang yang telah mencapai tingkat tertentu dalam kehidupan spiritualnya. Hal ini juga

\footnotetext{
29 Sihombing, Menggugat Bakor Pakem, 43.

30 Sihombing, Menggugat Bakor Pakem, 41-43.
} 
mengarah pada orang yang telah belajar dan memahami eksistensi diri atau "sejatine Awak". Pengertian ini merujuk pada esensi Ilahi dalam diri manusia. Wujud dari esensi Ilahi ini adalah pemahaman terkait dengan segala sesuatu yang ada di alam semesta baik hal yang berwujud atau tidak berwujud.

Untuk memperoleh pemahaman tersebut diperlukan Laku sebagai mediator dalam mengeratkan hubungan spiritual antara manusia dan non-manusia. Laku dalam Aliran Aboge merupakan praktik keagamaan dan pengajaran yang mengarah pada tindakan simbolis spiritual untuk mencapai tingkat tertentu yaitu "Manunggaling Kawnlo Gusti" bersatunya manusia dengan Tuhan. Oleh karena itu, tindakan simbolis dalam praktik dan ajaran Aboge tersebut merupakan suatu bentuk rekontekstualisasi hubungan antara manusia dengan alam dan seisinya baik antara manusia atau non-manusia. Secara ilmiah ritual Aboge mengarah pada hubungan intersubjektivitas antara manusia dan non-manusia yang mana orang Aboge memahami alam semesta dan juga isinya sebagai person/orang. Oleh karena itu, ritual seperti halnya ritual Ngembong merupakan suatu tindakan hubungan timbal balik orang Aboge terhadap non-manusia untuk mengetahui esensi jati dirinya sehingga bias mengantarkan mereka kepada pemahaman tertinggi yaitu "Manunggaling Kawulo Gusti"'.

Praktik spiritualisme yang semacam ini merupakan sisi mistik ajaran Kejawen. Ajaran agama Jawa mengutamakan mistisisme yang tercermin dalam setiap kebudayaan masyarakat Jawa. Hal tersebut, dimaksudkan untuk menjaga keharmonisan antara manusia, alam dan Tuhan sebagai satu kesatuan yang utuh. Selain itu, tujuan utama dari mistisisme Jawa adalah tercapainya kesempurnaan sejati dalam kehidupan di dunia. Ritual dalam perspektif Kejawen tidak hanya tentang praktikpraktik keagamaan tetapi juga berfungsi untuk menjaga keseimbangan hubungan manusia dengan manusia, makhluk hidup lain, alam dan Tuhan. Oleh karena itu, dapat disederhanakan bahwa praktik dan ajaran Aboge tidak bias dilepaskan dari ajaran Kejawen yang mengutamakan harmonisasi di antara beberapa aspek kehidupan. Akan tetapi, ragam kekayaan spiritual semacam ini sering kali disalahpahami bagi sebagian besar masyarakat agama mayoritas karena adanya anggapan 
penyimpangan ajaran keagamaan. Untuk itu, kegiatan-kegiatan kegiatan spiritual tersebut tidak bias lepas dari intervensi Negara sebagai pemegang kekuasaan tertinggi dalam sistem pemerintahan.

Negara melalui undang-undang yang sudah ditetapkan dalam pasal 1 nomor 2 PNPS 1965 penodaan dan penyalahgunaan agama dan juga tentang peraturan menteri agama tahun 1952 tentang definisi Aliran kepercayaan dengan jelas menjelaskan bahwa segala bentuk penafsiran terkait dengan agama-agama tertentu dianggap sebagai kejahatan. Penafsiran tersebut secara langsung merujuk pada Aliran kepercayaan yang mana tidak diakui sebagai agama yang sah di Indonesia. Kaitannya dengan Aliran Aboge adalah stigma dan stereotip sesat oleh masyarakat terhadap penganut Aboge karena selain dianggap sebagai ajaran dan praktik yang menyimpang, Aboge juga bukan termasuk dalam kategori agama yang diakui oleh Negara. Oleh karena itu, intervensi negara melalui beberapa kebijakan memiliki pengaruh besar terhadap kehidupan beragama di Indonesia terutama terhadap Aliran Kepercayaan. Hal ini dapat dilihat dari beberapa kasus seperti sulitnya mendapatkan hak-hak kewarganegaraan karena Aliran kepercayaan dinilai belum beragama.

\section{Daftar Pustaka}

Afandi, Fachrizal. "PAKEM: Salah Satu Upaya Negara dalam Melindungi Agama". Dalam al-Qânûn. Vol. 12 No. 2, Desember 2009.

Afdillah, Muhammad. Agama Jawi. Dalam Al-Afkar: Jurnal Kajian Keislaman, Vol. 3, No. 2 Desember 2010.

Baso, Ahmad. UU NO. 1/PNPS/1965 dan Soal "Agama Resmi" Itu: Sebuah Tatapan untuk JPS. Makalah dipresentasikan dalam Rakernas Perencanaan Strategis Jaringan Pokja-pokja Jamaah Persaudaraan Sejati di Puncak, Ciloto, 2004.

Bird-David, Nurit. Animism Revisited: Personbood, Environment, and Relational Epistemology 1. In Current Anthropology 40.S1, 1999: S67-S91.

Deddy, Mulyana, dan Jajaludin Rahmat. Komunikasi Antar Budaya. Bandung: Remaja Rosda Karya, 1993.

110 Moch. Ichiyak Ulumuddin - Aliran Kejawen Aboge di antara Agama dan Negara 
Dwiyanto, Djoko. Bangkitnya Penghayat Kepercayaan Terbadap Tuhan Yang Maha Esa: Hasil Studi di Daerah Istimewa Yogyakarta. Yogyakarta: Ampera Utama, 2011.

Endaswara, Suwardi. Falsafah Hidup Jawa. Tanggerang: Penerbit Cakrawala, 2003.

Endraswara, Suwardi. Mistike Kejawen: Sinkretisme, Simbolisme, Dan Sufisme Dalam Budaya Spiritual Jawa. Yogyakarta: Penerbit Narasi, 2003.

Geertz, Clifford. The Religion of Java. Chicago: University of Chicago Press: 1976.

Hakiki, Kiki Muhamad. Politik Identitas Agama Lokal (Studi Kasus Aliran Kebatinan). Analisis: Jurnal Studi Keislaman 11.1, 2014: 159-174.

Hallowell, A. Irving. "Ojibwa Ontology, Behavior, and World View". Dalam Graham Harvey (ed.). Readings in Indigenous Religions. New York, NY: Continuum, 2002.

Indonesia, Republik. Undang-undang Nomor 23 Tabun 2006 tentang Administrasi Kependudukan. Lembaran Negara Republik Indonesia Nomor 4674.

Kartapradja, Kamil. Aliran Kebathinan dan Kepercayaan di Indonesia. Jakarta: Yayasan Masagung, 1985.

Kholiludin, Tedi. Kuasa Negara atas Agama Politik Pengakuan: Diskursus Agama Resmi dan Diskriminasi Hak Sipil. Semarang: Rasail Media Group, 2009.

Langaji, Abbas. Dinamika Aliran Keagamaan Sempalan: Tinjauan Perspektif Sosiologi Agama. Dalam Conference Proceeding Annual Internasional Conference on Islamic Studies (AICIS) 2013.

Lubis, M. Ridwan. "Kebijakan Pembangunan Agama di Indonesia dalam Lintasan Sejarah". Dalam Harmoni: Jurnal Multikultural Multireligius. Vol. 9 No. 34, 2010.

Maarif, Samsul. Ammatoan Indigenous Religion and Forest Conservation. In Worldviews: Global Religions, Culture, and Ecology 19.2, 2015: 144-160. 
Mufid, Achmad Syafi'i. Dinamika Perkembangan Sistem Kepercayaan Lokal di Indonesia. Jakarta: Kementerian Agama RI, Badan Litbang dan Diklat, Puslitbang Kehidupan Keagamaan, 2012.

Muhammad, Damami. Makna Agama Dalam Masyarakat Jawa. Yogyakarta: LESEL, 2002.

Mulder, JA Niels, and Alois A. Nugroho. Kebatinan dan Hidup Sehari-hari Orang Jawa: Kelangsungan dan Perubahan Kulturil. Jakarta: PT Gramedia, 1984.

Mulder, Niels. Mistisisme Jawa: Ideologi di Indonesia, ter. Noor Cholis. Yogyakarta: LkiS, 2001.

Nasruddin. Kebudayaan dan Agama Jawa dalam Perspective Clifford Geert: Dalam Jurnal Religion Universitas Negeri Surabaya, Volume 03 Nomor 01 Tahun 2013, 98-106.

Picard Michel and Medinier Remy. The Politics of Religion in Indonesia, Syncretism, Orthodoxy, and Religious Contection in Java and Bali. New York, NY: Routledge, 2011.

Prabowo, Dhanu Priyo. Pandangan hidup Kejawen dalam Serat Pepali Ki Ageng Sela. Yogyakarta: Narasi, 2004.

Pratiwi, Ria Ayu Cahyaning. Pelaksanaan Pasal 64 Ayat (2) Undang-Undang Nomor 23 Tabun 2006 tentang Administrasi Kependudukan terkait dengan Pendaftaran Pernikahan bagi Penghayat Kepercayaan (Studi Di Kantor Catatan Sipil Kota Surabaya). Jurnal Mahasiswa Fakultas Hukum, 2014.

Purwadi. Tasawnf Jawa. Yogyakarta: Penerbit Narasi, 2003.

Ramstedt, Martin. Hinduism In Modern Indonesia A Minority Religion Between Local, National And Global Interest. London: Routledge, 2005.

Sairin, Weinata, and Joseph Marcus Pattiasina. Pelaksanaan UndangUndang Perkawinan Dalam Perspektif Kristen: Himpunan Telaah Tentang Perkawinan Di Lingkungan Persekutuan Gereja-Gereja Di Indonesia. BPK Gunung Mulia, 1994.

112 Moch. Ichiyak Ulumuddin - Aliran Kejawen Aboge di antara Agama dan Negara 
Sihombing, Uli Parulian. Menggugat Bakor Pakem: Kajian Hukum terhadap Pengawasan Agama Dan Kepercayaan di Indonesia. Jakarta: Indonesian Legal Resource Center (ILRC), 2008.

Subagya, Rachmat. Agama Asli Indonesia. Jakarta: Cipta Loka Caraka, 1981

- Kepercayaan Kebatinan, Kerohanian, Kejiwaan Dan Agama. Yogyakarta: Yayasan Kanisius, 1976.

Sujamto. Reorientasi Dan Revitalisasi Pandangan Hidup Jawa. Ed. 2 (rev). Semarang: Dahara Prize, 1992.

Sunyoto, Agus. Wali Songo: Rekonstruksi Sejarah yang Disingkirkan. Yogyakarta: Transpustaka, 2011.

Syafiie, Inu Kencana dkk. Ilmu Administrasi Publik. Jakarta: PT Rineka Cipta, 1999.

Badan Pusat Statisik. Sensus Penduduk Propinsi DKI Jakarta, 2010.

Van Der Kroef, M, Justus, Folklore And Tradition In Javanese Society. American Folklore Society, The Journal Of American Folklore, Vol. 68, No. 267, Jan-Mar, 1995. 